http://jmscr.igmpublication.org/home/ ISSN (e)-2347-176x ISSN (p) 2455-0450

crossref DOI: https://dx.doi.org/10.18535/jmscr/v9i1.14

\title{
Study of IgM seropositivity for Rubella virus in clinically suspected cases of Congenital Rubella infection
}

\author{
Authors \\ Dr Shaik Nazreen, Dr B. Manjula*, Dr P. Kamala \\ Department of Microbiology, Andhra Medical College, Visakhapatnam, India \\ *Corresponding Author \\ Dr B. Manjula
}

\begin{abstract}
Background: Epidemiological data about Rubella syndrome is scarce and Rubella vaccine is included in the National Immunization schedule (NIS) in India. This study aims to identify IgM seropositivity for Rubella virus in clinically suspected cases of Congenital Rubella.

Materials and Methods: Between January 2017 to March 2018, 15 blood samples of neonates with clinically suspected Rubella were collected and tested for IgM antibodies by ELISA.

Results: Out of 15 samples tested, 3 were positive (20\%). All 3 serologically positive cases expired. And the mothers of the children are clinically asymptomatic.

Conclusion: This study documented the threat of Congenital Rubella syndrome (CRS) and importance of antenatal screening for Rubella infection for future prevention of CRS cases which is the part of WHO control program.

Keywords: Rubella virus, IgM seropositivity, CRI, CRS, PDA, antenatal screening.
\end{abstract}

\section{Introduction}

Rubella virus belongs to Togaviridae family under genus Rubivirus. It is a positive sense, singlestranded RNA virus measuring $50-70 \mathrm{~nm}$ in size, surrounded by capsid (C) protein.

It is enveloped by a lipid layer which contains E1 and E2 spike-like glycoproteins.

It has only one serotype, and humans are known reservoir. $^{(1)}$

Viral RNA replicates in the cytoplasm of infected cells with non-structural proteins being translated from $5^{\mathrm{I}}$ two-thirds of genomic RNA and structural proteins being translated from subgenomic RNA that is a copy of $3^{\mathrm{I}}$ one-third of genomic RNA.
New virions are produced when genomic RNA, E1 and E2 glycoproteins and C protein assemble at cellular membranes.

At present, 12 genotypes and one provisional genotype of rubella viruses have been recognized. Immunity to one rubella virus is sufficient to protect against clinical disease caused by other known rubella viruses. ${ }^{(2)}$

It spreads from person to person via respiratory droplets, transplacental and rarely via contact and sexual modes.

Sensorineural deafness is the most common defect of Congenital Rubella Syndrome (CRS) followed by Salt and pepper retinopathy, cataract, Patent Ductus Arteriosus (PDA) and CNS manifestations 
such as microcephaly, mental retardation, motor delay and autism are seen.

Transient changes such as hepatosplenomegaly, bone lesion, IUGR and thrombocytopenia with petechiae (Blueberry muffin syndrome) may be seen. ${ }^{(1)}$

If congenital defects characteristic of CRS were not present, the infant is diagnosed as having Congenital Rubella Infection (CRI) only.

Diagnosis is based on detection of rubella virus (RT-PCR) or rubella virus-specific IgM in such patients.

CRI results in both shedding of virus and $\operatorname{IgM}$ antibodies in the neonate. ${ }^{(2)}$

The most devastating consequences of rubella infection during pregnancy are abortion, stillbirth and fetal malformation that arise from maternal infection during the first trimester of pregnancy. (3)

Epidemiological data about Rubella syndrome is scarce, and Rubella vaccine is included in the National Immunization Schedule (NIS) in India.

\section{Aims and Objectives}

This study aims to identify IgM seropositivity for Rubella virus in clinically suspected cases of Congenital Rubella Infection.

\section{Materials and Methods}

Study population: ${ }^{(4)}$

- Neonates with suspected intrauterine infection.

- Newborn with congenital malformations.

- Pregnant women with bad obstetric history.

Study Period: Jan 2017 - March 2018

Study Procedure: ${ }^{(5)}$

- All subjects were personally interviewed, and a standardized questionnaire was filled up for each of them to obtain relevant demographic, anthropometric, socioeconomic, clinical and health-related information.

- Each participant was provided with an identification number (ID) which was subsequently used for the serodiagnosis, data entry and analysis.

\section{Specimen Collection}

From each participant, approximately $2-3 \mathrm{ml}$ of blood was collected. Serum was separated from the blood sample using the standard method. ${ }^{(5)}$

\section{Specimen Processing}

Between January 2017 to March 2018, 15 blood samples of neonates with clinically suspected Rubella were collected and tested for IgM antibodies by ELISA using EUROIMMUN Rubella kit.

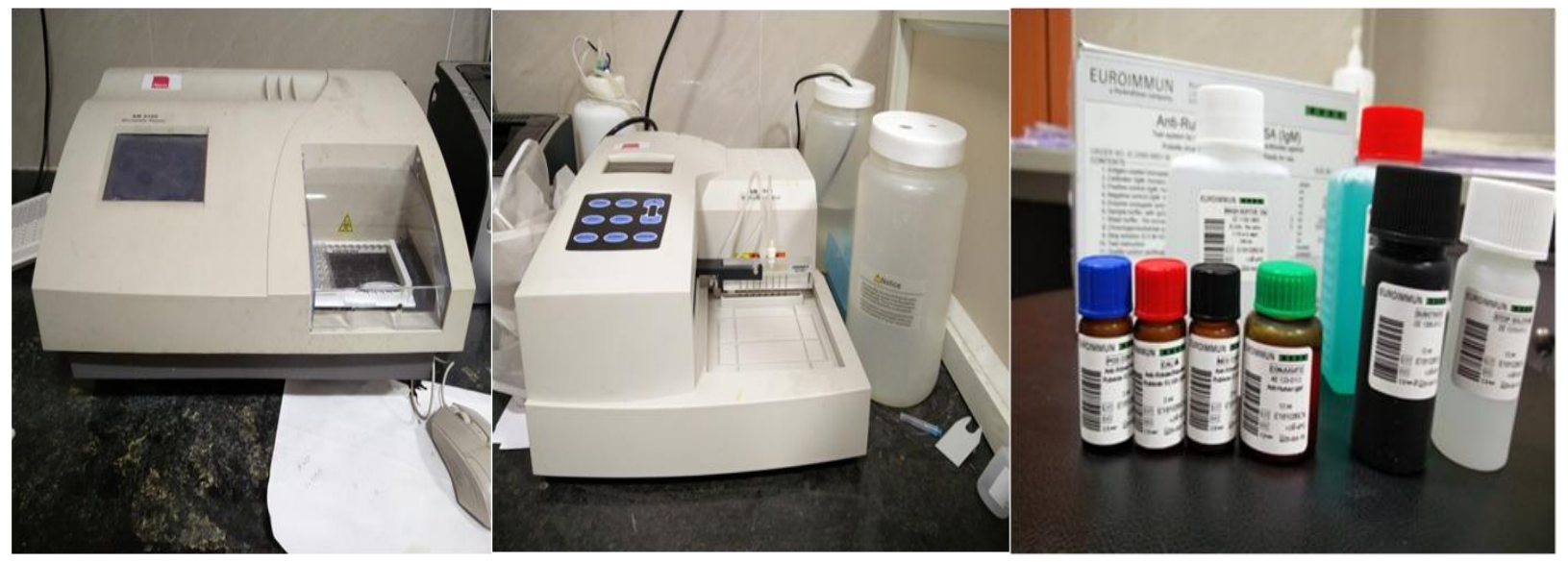




\section{Results}

$>$ Out of the 15 samples tested, three were positive (20\%).

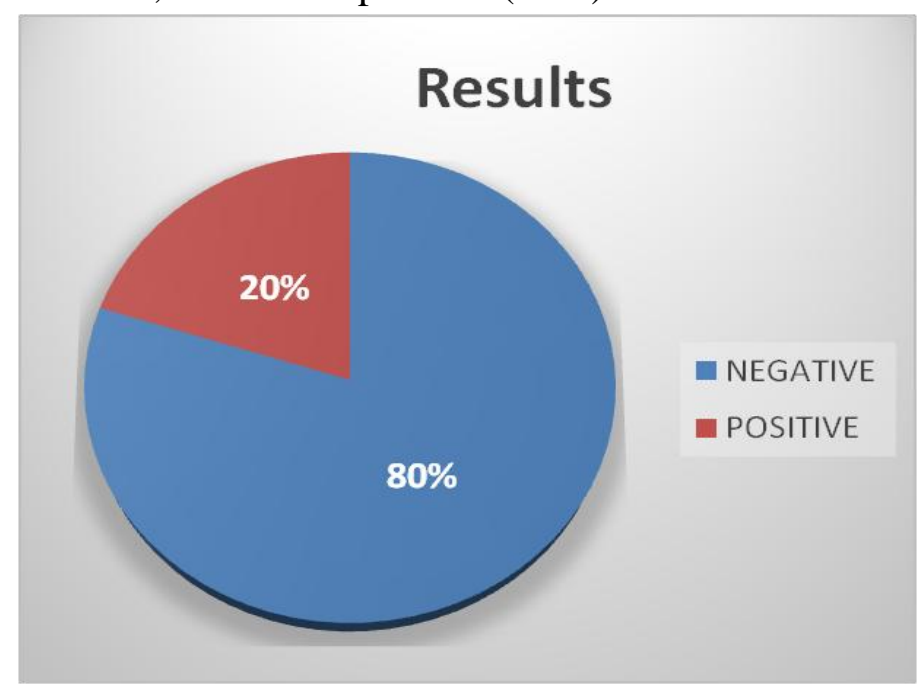

From 3 positives, 2 were males, and one was female.

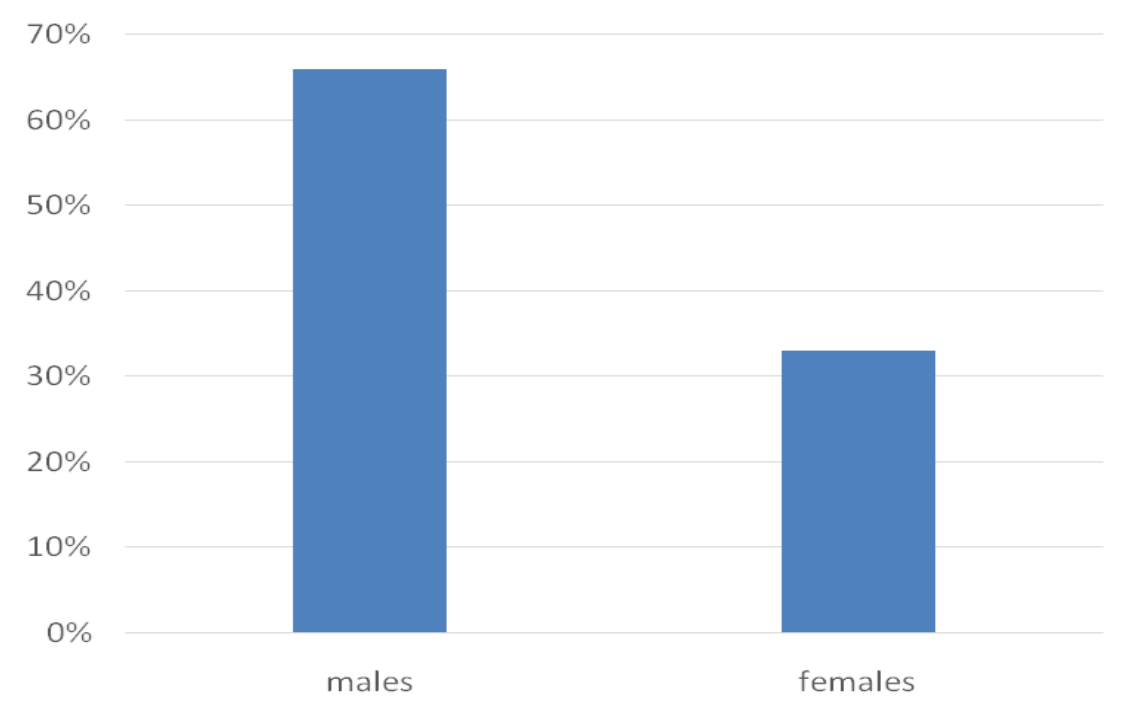

Among studied cases, most of the pregnant mothers had a bad obstetric history, and systemic complications of CRS such as PDA, hepatosplenomegaly and neonatal jaundice were reported in newborn babies.

\begin{tabular}{|l|l|l|l|l|}
\hline Authors & Year & $\begin{array}{l}\text { Total } \\
\text { Samples }\end{array}$ & $\begin{array}{l}\text { Total } \\
\text { positive }\end{array}$ & $\begin{array}{l}\text { Positive } \\
\text { percentage }\end{array}$ \\
\hline Ballal M et al & 1997 & 342 & 52 & $15.2 \%$ \\
\hline Broor S et al & 1991 & 249 & 30 & $12 \%$ \\
\hline $\begin{array}{l}\text { Rajasundari } \\
\text { TA et al }\end{array}$ & 2008 & 65 & 26 & $40 \%$ \\
\hline $\begin{array}{l}\text { Present study } \\
2018\end{array}$ & 15 & & $20 \%$ \\
\hline
\end{tabular}




\section{Discussion}

- In a study done by Ballal $\mathrm{M}$ et al., $15.2 \%$ of children were seropositive for rubella $\operatorname{IgM}$ which is consistent with this study $(20 \%)^{(6)}$

- Among 3 CRS patients, the male-female ratio was $2: 1$. It was unclear why the male child was predominant in CRS cases, but in many studies, the male-female ratio was almost the same.

- The pattern of systemic manifestations in CRS varied in different studies. Most authors documented ocular problem as the predominant manifestation of CRS, whereas hearing defect was the commonest in other studies. Neurological problems were next common CRS manifestation followed by congenital heart disease.

- In our study, the cardiac defect was found in the majority of children.

- Regarding the pattern of cardiac problems, PDA was reported as predominant congenital heart disease (CHD) by several authors followed by pulmonary stenosis. It is consistent with this study. ${ }^{(3)}$

\section{Conclusion}

$\checkmark$ The outcome in the neonates is death with congenital defects such as PDA and neonatal jaundice in one case and hepatosplenomegaly in other. The third case is clinically not identified.

$\checkmark$ Rubella is a major public health problem, and CRS presents with a diverse form of clinical patterns which increases childhood morbidity and mortality.

$\checkmark$ This study documented the threat of CRS and the importance of antenatal screening for Rubella infection for future prevention of CRS cases which is the part of the WHO control program.

\section{References}

1. Sankar Sastry A, Bhat K S. Essentials of Medical Microbiology. Jaypee Brothers. 2019. 490-491 p.

2. Topley WWC, Wilson SGS. Topley and Wilson's Microbiology and Microbial Infections, 8 Volume Set, 10th Edition. Journal of Infection. 1999. 5634-5639 p.

3. Nazme NI, Hoque MM, Hussain $M$. Congenital Rubella Syndrome: An Overview of Clinical Presentations in Bangladeshi Children. Delta Med Coll J. 2014;2(2):42-7.

4. Dewan P, Gupta P. Burden of congenital rubella syndrome (CRS) in India: A systematic review. Indian Pediatr. 2012;49(5):377-99.

5. Imam H, Yasmin M, Ahsan CR, Nessa J. Pregnant Women in and Around Dhaka City: Are Their Children at Risk of Developing Congenital Rubella Syndrome? Indian J Microbiol. 2010;50(4):443-8.

6. Ballal M, Shivananda FG. Prevalence of Rubella Virus in Suspected Cases of Congenital Infections. Indian J Pediatr. 1997;64(2):231-5.

7. Broor S, Kapil A, Kishore J, Seth P. Prevalence of rubella virus and cytomegalovirus infections in suspected cases of congenital infections. Indian $\mathbf{J}$ Pediatr. 1991;58(1):75-8.

8. Rajasundari TA, Sundaresan P, Vijayalakshmi P, Brown DWG, Jin L. Laboratory confirmation of congenital rubella syndrome in infants: An eye hospital-based investigation. J Med Virol. 2008;80(3):536-46.

9. Bhandary SK, Shwetha Shenoy M, Bhat VS, Biniyam K, Shenoy V. Congenital rubella syndrome: It still exists in India. J Clin Diagnostic Res. 2012;6(2):301-2. 